\title{
DETERMINASI KESELAMATAN DAN KESEHATAN KERJA (K3), DAN KOMUNIKASI INTERPERSONAL TERHADAP KINERJA KARYAWAN PADA P.T PARDIC JAYA CHEMICAL, TANGERANG.
}

\author{
Kamsanuddin Hsb, Eris Rismawan \\ Dosen Fakultas Ekonomi dan Bisnis Program Studi Manajemen \\ Universitas Muhammadiyah Tangerang
}

\begin{abstract}
Abstrak
Penelitian ini tergolong pada penelitian kuantitatif. Populasi terdiri dari 5lorang dengan teknik pengambilan sampel Non Probability Sampling dengan jenis sampel jenuh.

Berdasarkan output SPSS versi 19 diketahui pengaruh keselamatan dan kesehatan kerja (K3) terhadap kinerja sangat kuat dengan koefisien korelasi ( $r$ ) $=0,900$, sedangkan koefisien determinasi $(R)=80,9 \%$ dengan keyakinan $95 \%$ diperoleh perbandingan $t$ hitung $X_{1}(14,426)>t$ tabel $(1,677)$, dan Sig. 0,000 < 0,05 . Pengaruh komunikasi interpersonal terhadap kinerja sangat kuat dengan koefisien korelasi $(r)=0,817$, sedangkan koefisien determinasi $(R)=66,7 \%$ dengan keyakinan 95\% diperoleh perbandingan $t$ hitung $X_{2}(9,916)>t$ tabel (1,677), dan Sig. 0,000 <0,05. Pengaruh keselamatan dan kesehatan kerja (K3) dan komunikasi interpersonal secara simultan terhadap kinerja sangat kuat dengan koefisien korelasi sebesar 0,946. Koefisien determinasi $(R)=89,4 \%$ sisanya $(10,6 \%)$ dipengaruhi variabel lain yang tidak masuk dalam penelitian ini, dan dengan keyakinan 95\% diperoleh perbandingan $F$ hitung $(203,026)>F$ tabel (3,178), dan signifikansi 0,00 <0,05.
\end{abstract}

Kata kunci: Keselamatan dan Kesehatan Kerja, Komunikasi Interpersonal, Kinerja Karyawan

\section{PENDAHULUAN}

\section{A. Latar Belakang}

Dewasa ini di mana tingkat persaingan organisasi atau perusahaan baik di dalam dan luar negeri yang semakin ketat mengharuskan organisasi mampu menyediakan berbagai sarana, fasilitas dan serta kebutuhan penunjang lainnya bagi karyawan dalam rangka meningkatkan kinerja agar perusahaan mampu bersaing dengan perusahaan lainnya. Kinerja merupakan tolok ukur keberhasilan perusahaan secara umum melalui unjuk kerja oleh para pekerja.

$\begin{array}{llr}\text { Kinerja } & \text { yang } & \text { tinggi } \\ \text { merupakan } & \text { dambaan } & \text { setiap } \\ \text { perusahaan. Kinerja bisa diartikan } \\ \text { sebagai hasil yang bisa } & \text { dicapai }\end{array}$


seseorang dibandingkan dengan target atau sasaran yang disepakati bersama. Sesuai dengan pendapat Sedarmayanti (2013: 263) bahwa, "kinerja adalah hasil kerja seseorang karyawan selama periode tertentu dibandingkan dengan berbagai kemungkinan, misalnya standar, target/sasaran/kriteria yang ditentukan dan disepakati bersama" dan pendapat Kusriyanto dalam Mangkunagara (2014: 9) bahwa, "kinerja adalah perbandingan hasil yang dicapai dengan peran serta tenaga kerja persatuan waktu (lazimnya per jam)".

Salah satu upaya untuk mewujudkan hal tersebut adalah diterapkannya keselamatan dan kesehatan kerja (K3) sebagai salah satu dari program pemeliharaan karyawan. UndangUndang No.1 Tahun 1970 Tentang Keselamatan Kerja merupakan payung hukum perlindungan tenaga kerja pada perusahaan. Pasal 86 menyebutkan bahwa setiap organisasi wajib menerapkan upaya keselamatan dan kesehatan kerja untuk melindungi keselamatan tenaga kerja.

Keselamatan dan kesehatan kerja adalah kondisi di mana para pekerja merasa aman dalam melakukan pekerjaannya dan terhindar dari berbagai ancaman bahaya yang dapat mengakibatkan cedera, penyakit, kerusakan harta benda, gangguan lingkungan, dan kerusakan lainnya. Menurut Ridley dalam Nurjaman (2014: 289) bahwa, "keselamatan dan kesehatan kerja adalah kondisi dalam pekerjaan yang sehat dan aman, baik bagi pekerjanya, perusahaan maupun masyarakat dan lingkungan sekitar pabrik atau tempat kerja tersebut. Menurut Kamus Besar Bahasa Indonesia dalam Widodo (2015: 233) bahwa, "keselamatan dan kesehatan kerja adalah suatu kondisi kerja yang terbebas dari ancaman bahaya yang menggangu proses aktivitas dan mengakibatkan terjadinya cedera, penyakit, kerusakan harta benda, serta gangguan lingkungan".

Selain penerapan K3 secara konsekwen, komunikasi interpersonal juga berpengaruh pada kinerja karyawan, karena komunikasi merupakan urat nadi organisasi, dan komunikasi interpersonal yang efektif dapat membantu proses pekerjaan lebih lancar dan terarah sesuai dengan rencana yang sudah ditetapkan.

Komunikasi interpersonal adalah komunikasi yang dilakukan oleh dua orang atau lebih secara tatap muka di mana pengirim dapat menyampaikan pesan secara langsung, dan penerima pesan menanggapi secara langsung. Hal ini sesuai dengan pendapat Suharsono dan Lukas (2013: 86) bahwa, "komunikasi interpersonal adalah bentuk komunikasi tatap muka langsung, dialogis antara kedua individu dengan individu, individu dengan kelompok maupun kelompok dengan kelompok.

\section{B. Rumusan Masalah}

Berdasarkan latar belakang di atas, maka yang menjadi rumusan 
masalah dalam penelitian ini adalah:

1. Bagaimana pengaruh keselamatan dan kesehatan kerja (K3) terhadap kinerja karyawan PT. PJC?

2. Bagaimana pengaruh komunikasi interpersonal terhadap kinerja karyawan pada PT. PJC?

3. Berapa besar pengaruh keselamatan dan kesehatan kerja (K3) dan komunikasi interpersonal secara simultan terhadap kinerja karyawan pada PT. PJC?

\section{TINJAUAN PUSTAKA}

Harold Koontz dan Cylril O'Donell dalam Nurjaman (2014: 15) menyebutkan bahwa, "manajemen adalah usaha untuk mencapai tujuan tertentu melalui kegiatan orang lain". Gary Dessler dalam Widodo (2015: 2) menyatakan bahwa, "manajemen sumber daya manusia adalah proses memperoleh, melatih, menilai dan penugasan yang tepat, agar sesuai dengan kebutuhan dan tujuan organisasi”.

Menurut Ridley dalam Nurjaman (2014: 289) keselamatan dan kesehatan kerja adalah, kondisi dalam pekerjaan yang sehat dan aman, baik bagi pekerjanya, perusahaan maupun masyarakat dan lingkungan sekitar tempat kerja tersebut.

Menurut Hardjana dalam Suharsono dan Lukas (2013: 87), "komunikasi interpersonal adalah interaksi tatap muka antar dua orang atau beberapa orang, di mana pengirim dapat menyampaikan pesan secara langsung, dan penerima pesan dapat menerima dan menanggapi secara langsung pula".

Suwatno dan Priansa (2011: 196) menyatakan bahwa, "kinerja merupakan hasil yang dicapai seseorang menurut ukuran yang berlaku, dalam kurun waktu tertentu, berkenaan dengan pekerjaan serta perilaku dan tindakannya". Sedangkan Sedarmayanti (2013: 263) menyatakan, bahwa kinerja adalah hasil kerja seseorang karyawan selama periode tertentu dibandingkan dengan berbagai kemungkinan, missal: standar, target, sasaran, tu kriteria yang ditentukan dan disepakati bersama.

\section{METODE PENELITIAN dan PEMBAHASAN.}

\section{A. Populasi dan Sampel}

Populasi dalam penelitian ini adalah seluruh karyawan tetap pada bagian lapangan PT. Pardic Jaya Chemicals yang berjumlah 51 orang. Teknik yang digunakan dalam pengambilan sampel adalah Non Probability Sampling dengan jenis sampel jenuh. Menurut Sugiyono (2013 : 68) sampling jenuh adalah teknik penentuan sampel bila semua anggota populasi digunakan sebagai sampel. 


\section{B. Analisis Data}

Penelitian ini terdiri atas dua variable bebas dan satu variable terikat. Variable bebas adalah Keselamatan dan Kesehatan Kerja $\left(\mathrm{X}_{1}\right)$, Komunikasi Interpersonal $\left(\mathrm{X}_{2}\right)$, dan variael terikatnya adalah Kinerja (Y).

\begin{tabular}{|c|c|c|}
\hline \multicolumn{3}{|c|}{ Statistics } \\
\hline \multicolumn{3}{|c|}{ K3 } \\
\hline \multirow[t]{2}{*}{$\mathrm{N}$} & Valid & 51 \\
\hline & Missing & 0 \\
\hline \multicolumn{2}{|c|}{ Mean } & 45,9412 \\
\hline \multicolumn{2}{|c|}{ Median } & 47,0000 \\
\hline \multicolumn{2}{|c|}{ Mode } & 50,00 \\
\hline \multicolumn{2}{|c|}{ Std. Deviation } & 3,34312 \\
\hline \multicolumn{2}{|c|}{ Variance } & 11,176 \\
\hline \multicolumn{2}{|c|}{ Range } & 10,00 \\
\hline \multicolumn{2}{|c|}{ Minimum } & 40,00 \\
\hline \multicolumn{2}{|c|}{ Maximum } & 50,00 \\
\hline \multicolumn{2}{|c|}{ Sum } & 2343,00 \\
\hline
\end{tabular}

a. Deskripsi data variabel Keselamatan dan Kesehatan Kerja $\left(\mathrm{X}_{1}\right)$

Hasil penyebaran data variabel Keselamatan dan Kesehatan Kerja setelah dianalisa dapat dilihat tabel, dan histogram berikut yang diolah menggunakan SPSS versi 19

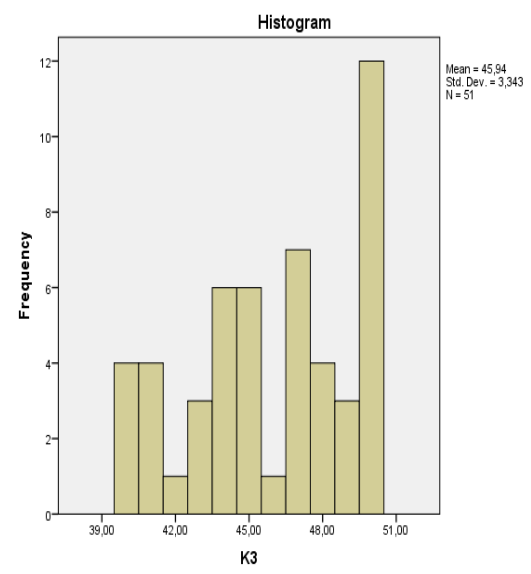

\section{b. Deskripsi Data Variabel Komunikasi Interpersonal $\left(\mathbf{X}_{2}\right)$}

Penyebaran data variabel $\mathrm{X}_{2}$ setelah dianalisa ditunjukkan dalam tabel, dan histogram yang

\begin{tabular}{|c|c|c|}
\hline \multicolumn{3}{|c|}{ Statistics } \\
\hline \multicolumn{3}{|c|}{ Komunikasi Interpersonal } \\
\hline \multirow[t]{2}{*}{$\mathrm{N}$} & Valid & 51 \\
\hline & Missing & 0 \\
\hline \multicolumn{2}{|c|}{ Mean } & 44,4118 \\
\hline \multicolumn{2}{|c|}{ Median } & 45,0000 \\
\hline \multicolumn{2}{|c|}{ Mode } & 45,00 \\
\hline \multicolumn{2}{|c|}{ Std. Deviation } & 2,95416 \\
\hline \multicolumn{2}{|c|}{ Variance } & 8,727 \\
\hline \multicolumn{2}{|c|}{ Range } & 10,00 \\
\hline \multicolumn{2}{|c|}{ Minimum } & 39,00 \\
\hline \multicolumn{2}{|c|}{ Maximum } & 49,00 \\
\hline \multicolumn{2}{|c|}{ Sum } & 2265,00 \\
\hline
\end{tabular}

diolah menggunakan SPSS versi 19

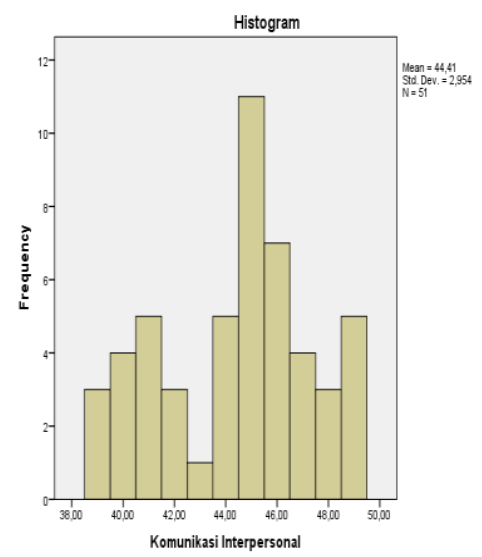


Deskripsi Data Varibel Kinerja (Y)

Hasil penyebaran data variabel kinerja setelah dianalisa

\begin{tabular}{|c|c|c|}
\hline \multicolumn{3}{|c|}{ Statistics } \\
\hline \multicolumn{3}{|c|}{ Kinerja } \\
\hline \multirow[t]{2}{*}{$\mathrm{N}$} & Valid & 51 \\
\hline & Missing & 0 \\
\hline \multicolumn{2}{|c|}{ Mean } & 46,3725 \\
\hline \multicolumn{2}{|c|}{ Median } & 47,0000 \\
\hline \multicolumn{2}{|c|}{ Mode } & 50,00 \\
\hline \multicolumn{2}{|c|}{ Std. Deviation } & 2,99306 \\
\hline \multicolumn{2}{|c|}{ Variance } & 8,958 \\
\hline \multicolumn{2}{|c|}{ Range } & 10,00 \\
\hline \multicolumn{2}{|c|}{ Minimum } & 40,00 \\
\hline \multicolumn{2}{|c|}{ Maximum } & 50,00 \\
\hline \multicolumn{2}{|c|}{ Sum } & 2365,00 \\
\hline
\end{tabular}

\section{Uji Prasyarat Analisis}

1. Uji Validitas

Menurut Sunyoto (2011: 72), uji validitas dapat dilakukan dengan cara membandingkan nilai $r$ hitung dengan nilai $r$ tabel untuk degree of freedom $=\mathrm{n}-\mathrm{k}$. Jika $\mathrm{r}$ hitung lebih besar dari $r$ tabel maka pernyataan tersebut dikatakan valid.

a. Uji validitas variabel $\mathrm{X}_{1}$ ditunjukkan dalam tabel, dan histogram yang diolah menggunakan SPSS versi 19.

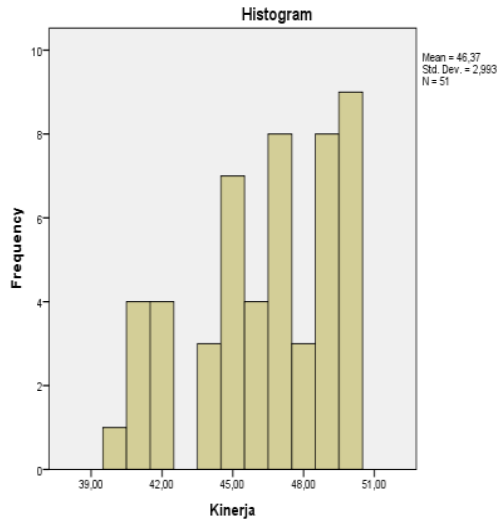

Berdasarkan output corrected item-total correlation besarnya nilai $\mathrm{r}$ tabel $\left(\mathrm{X}_{1}\right)$ dengan tingkat signifikasi $5 \%$ diketahui sebesar 0,284 . Perbandingan antara $r$ tabel dengan setiap butir $r$ pernyataan, ternyata semuanya lebih besar dari 0,284 ( $\mathrm{r}$ tabel) sehingga dapat disimpulkan bahwa semua pernyataan sudah valid, ditunjukkan dalam tabel berikut.

\begin{tabular}{|c|c|c|c|}
\hline No & r-hitung & r-tabel & Keterangan \\
\hline 1 & 0,828 & 0,2759 & Valid \\
\hline 2 & 0,653 & 0,2759 & Valid \\
\hline 3 & 0,786 & 0,2759 & Valid \\
\hline 4 & 0,770 & 0,2759 & Valid \\
\hline 5 & 0,731 & 0,2759 & Valid \\
\hline 6 & 0,734 & 0,2759 & Valid \\
\hline 7 & 0,565 & 0,2759 & Valid \\
\hline 8 & 0,674 & 0,2759 & Valid \\
\hline
\end{tabular}




\begin{tabular}{|c|c|c|c|}
\hline 9 & 0,451 & 0,2759 & Valid \\
\hline 10 & 0,599 & 0,2759 & Valid \\
\hline
\end{tabular}

b. Uji validasi variabel $\mathrm{X}_{2}$

Nilai $r_{\text {tabel }}\left(\mathrm{X}_{2}\right)$ dengan tingkat signifikasi $5 \%$ diketahui sebesar 0,284 . Bila $r$ hitung berdasarkan output corrected item-total correlation dibandingkan dengan $r$ tabel ternyata nilai $r$ hitung semuanya lebih besar dari $\mathrm{r}$ tabel $(0,284)$ sehingga dapat disimpulkan bahwa semua pernyataan $\left(\mathrm{X}_{2}\right)$ sudah valid, ditunjukkan dalam tabel berikut.

\begin{tabular}{|c|c|c|c|}
\hline No & r-hitung & r-tabel & Keterangan \\
\hline 1 & 0,392 & 0,284 & Valid \\
\hline 2 & 0,587 & 0,284 & Valid \\
\hline 3 & 0,557 & 0,284 & Valid \\
\hline 4 & 0,621 & 0,284 & Valid \\
\hline 5 & 0,559 & 0,284 & Valid \\
\hline 6 & 0,613 & 0,284 & Valid \\
\hline 7 & 0,424 & 0,284 & Valid \\
\hline 8 & 0,541 & 0,284 & Valid \\
\hline 9 & 0,677 & 0,284 & Valid \\
\hline 10 & 0,615 & 0,284 & Valid \\
\hline
\end{tabular}

c. Uji validitas variabel Y

Berdasarkan data yang tertera pada tabel di bawah diketahui bahwa nilai-nilai koefisien korelasi untuk uji validitas instrumen kinerja (Y) lebih besar dari r-tabel secara keseluruhan sehingga dapat dinyatakan valid.

\begin{tabular}{|c|c|c|c|}
\hline No & r-hitung & r-tabel & Keterangan \\
\hline 1 & 0,791 & 0,2759 & Valid \\
\hline 2 & 0,720 & 0,2759 & Valid \\
\hline 3 & 0,712 & 0,2759 & Valid \\
\hline 4 & 0,735 & 0,2759 & Valid \\
\hline 5 & 0,427 & 0,2759 & Valid \\
\hline 6 & 0,724 & 0,2759 & Valid \\
\hline 7 & 0,604 & 0,2759 & Valid \\
\hline 8 & 0,513 & 0,2759 & Valid \\
\hline 9 & 0,426 & 0,2759 & Valid \\
\hline 10 & 0,562 & 0,2759 & Valid \\
\hline
\end{tabular}

2. Uji Reliabilitas

Hasil penghitungan dengan bantuan aplikasi SPPS diperoleh nilai koefisien reliabilitas seperti tertera dalam di bawah ini. Berdasarkan tabel diketahui 
Cronbach's Alpha variabel $\mathrm{X}_{1}$ adalah 0,765 cronbach's Alpha variabel $\left(\mathrm{X}_{2}\right)$ adalah 0,765 sedangkan cronbach's Alpha variabel (Y) adalah 0,754. Mengacu kepada pendapat Sunyoto (2012: 114), bahwa, "suatu variabel dinyatakan reliabel jika cronbach alphanya > dari 0,6 dan tidak reliabel bila sama atau di bawah 0,60". Karena Cronbach's Alpha variabel $\mathrm{X}_{1}, \mathrm{X}_{2}$, dan $\mathrm{Y}$ ternyata berada di atas 0,6 maka dapat disimpulkan bahwa data setiap variabel sudah reliabel.

\begin{tabular}{|l|l|c|c|c|}
\hline No & \multicolumn{1}{|c|}{ Variabel } & $\begin{array}{c}\text { Koefisien } \\
\text { Reliability (Alpha) }\end{array}$ & $\begin{array}{c}\text { Alpha } \\
\text { Standard }\end{array}$ & Keterangan \\
\hline 1 & $\begin{array}{l}\text { Keselamatan dan } \\
\text { Kesehatan Kerja }\end{array}$ & 0,765 & 0,600 & Reliabel \\
\hline 2 & Komunikasi Interpersonal & 0,765 & 0,600 & Reliabel \\
\hline 3 & Kinerja & 0,754 & 0,600 & Reliabel \\
\hline
\end{tabular}

\section{Uji Asumsi Klasik}

\section{Uji Normalitas}

Uji normalitas bertujuan untuk mengetahui apakah populasi data atau instrumen penelitian berdistribusi normal atau tidak. Penelitian ini menggunakan analisis Kolmogorov-Smirnov Z Test, dengan ketentuan jika nilai pada Asymp.Sig.(2-tailed) > 0,05 maka distribusi data dinyatakan memenuhi asumsi normalitas, dan jika $<0,05$ berarti data tidak normal. Dan berdasarkan output SPSS berikut, uji normalitas untuk variabel $\mathrm{X}_{1}$ sebesar $0,318>0,05$, untuk variabel $\mathrm{X}_{2}$ sebesar $0,116>$ 0,05 , dan untuk variabel Y sebesar $0,264>0,05$. Semuanya berada di atas 0,05 dan dinyatakan telah memenuhi asumsi normalitas.

\begin{tabular}{|c|c|c|c|c|}
\hline \multicolumn{5}{|c|}{ One-Sample Kolmogorov-Smirnov Test } \\
\hline & & $\mathrm{X} 1$ & $\mathrm{X} 2$ & $\mathrm{Y}$ \\
\hline \multicolumn{2}{|l|}{$\mathrm{N}$} & 51 & 51 & 51 \\
\hline \multirow[t]{2}{*}{ Normal Parameters ${ }^{a, b}$} & Mean & 45,9412 & 44,4118 & 46,3725 \\
\hline & Std. Deviation & 3,34312 & 2,95416 & 2,99306 \\
\hline \multirow[t]{3}{*}{ Most Extreme Differences } & Absolute &, 134 &, 167 &, 143 \\
\hline & Positive &, 112 &, 111 &, 113 \\
\hline & Negative &,- 134 &,- 167 &,- 143 \\
\hline \multicolumn{2}{|l|}{ Kolmogorov-Smirnov Z } & ,957 & 1,194 & 1,024 \\
\hline \multicolumn{2}{|l|}{ Asymp. Sig. (2-tailed) } & ,318 &, 116 & ,246 \\
\hline \multicolumn{5}{|l|}{$\begin{array}{l}\text { a. Test distribution is Normal. } \\
\text { b. Calculated from data. }\end{array}$} \\
\hline
\end{tabular}




\section{Uji Multikolinieritas}

\begin{tabular}{|c|c|c|c|c|}
\hline \multicolumn{5}{|c|}{ Coefficients $^{\mathrm{a}}$} \\
\hline \multirow{2}{*}{\multicolumn{2}{|c|}{ Model }} & \multirow[b]{2}{*}{ Sig. } & \multicolumn{2}{|c|}{ Collinearity Statistics } \\
\hline & & & Tolerance & VIF \\
\hline \multirow[t]{3}{*}{1} & (Constant) & ,268 & & \\
\hline & K3 & ,000 &, 555 & 1,800 \\
\hline & Komunikasi Interpersonal &, 000 &, 555 & 1,800 \\
\hline
\end{tabular}

Berdasarkan output SPSS di atas tidak terjadi multikolinieritas. Menurut Sunyoto (2011: 82) jika toleransinya $10 \%$ atau lebih, maka dapat disimpulkan antar variabel bebas tidak terjadi multikolinieritas. Tabel menunjukkan toleransi variabel $\mathrm{X}_{1}$ adalah $(55,5 \%>10 \%)$, toleransi $X_{2}$ adalah $(55,5 \%>10 \%)$, sehingga dapat disimpulkan tidak terjadi multikolinieritas.

3. Uji Autokorelasi

Dilakukan dengan DurbinWatson test dengan ketentuan sebagai barikut: terjadi autokorelasi (+) jika nilai DW < 2 ; tidak terjadi autokorelasi jika nilai $-2 \leq \mathrm{DW} \leq+2$; dan terjadi autokorelasi (-) jika nilai DW > +2 .

Berdasarkan output SPSS Durbin-Watson test berikut diketahui nilai $\mathrm{DW}=1,750$ berarti posisi DW berada pada -2 $\leq \mathrm{DW} \leq+2$ sehingga dapat disimpulkan tidak terjadi autokorela

\begin{tabular}{|c|c|c|c|c|c|}
\hline \multicolumn{6}{|c|}{ Model Summary } \\
\hline Model & $\mathrm{R}$ & R Square & $\begin{array}{l}\text { Adjusted R } \\
\text { Square }\end{array}$ & $\begin{array}{l}\text { Std. Error of the } \\
\text { Estimate }\end{array}$ & Durbin-Watson \\
\hline 1 & $946^{a}$ & ,894 & ,890 & ,99323 & 1,750 \\
\hline
\end{tabular}

a. Predictors: (Constant), Komunikasi Interpersonal, K3

b. Dependent Variable: Kinerja

4. Uji Heterokedastisitas.

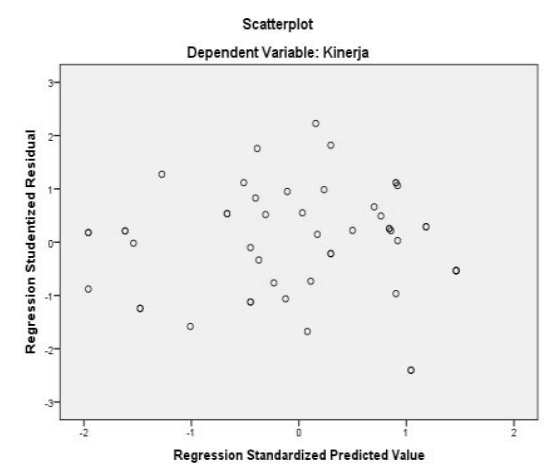

Uji Heteroskedastisitas dilakukan dengan mengeplotkan grafik antara SRESID dengan ZPRED, dan apabila terdapat gangguan heteroskedastisitas akan muncul pola tertentu pada grafik. Penelitian ini tidak mempunyai gangguan heteroskedastisitas karena titik-titik pada scatterplot terlihat relatif menyebar baik di atas maupun di bawah sumbu Y.

\section{E. Pengujian Hipotesis}

\section{Uji t (uji secara parsial)}

Untuk mengetahui hubungan antara variabel bebas dengan variabel terikat secara parsial, dilakukan melalui uji t. 
Berdasarkan tabel di bawah ini diketahui nilai $\mathrm{t}$ hitung untuk $\mathrm{X}_{1}$ adalah 14,426 sedangkan nilai $\mathrm{t}$ tabel dengan tingkat keyakinan 95\% adalah 1,677 sehingga diperoleh perbandingan $\mathrm{t}$ hitung $(14,426)>\mathrm{t}$ tabel $(1,677)$, Sig. $0,000<0,05$. Nilai t hitung untuk $\mathrm{X}_{2}$ adalah 9,916 sedangkan nilai $\mathrm{t}$ tabel berdasarkan keyakinan $95 \%$ adalah 1,677 sehingga diperoleh perbandingan $\mathrm{t}$ hitung $(9,916)>\mathrm{t}$ tabel (1,677), Sig. 0,000<0,05. Sesuai dengan kriteria uji hipotesis bahwa jika nilai t hitung $>\mathrm{t}$ tabel maka $\mathrm{H}_{\mathrm{o}}$ ditolak dan $\mathrm{H}_{\mathrm{a}}$ diterima, dan kriteria signifikansi jika Sig. $<0,05$ maka $\mathrm{H}_{\mathrm{o}}$ ditolak dan $\mathrm{H}_{\mathrm{a}}$ diterima. Sehingga dapat disimpulkan bahwa terdapat pengaruh positif yang signifikan antara Keselamatan dan Kesehatan Kerja (K3), Komunikasi Interpersonal, secara parsial dengan Kinerja, sehingga hipotesis yang berbunyi, variabel bebas (Keselamatan dan kesehatan Kerja, Komunikasi Interpersonal) masing-masing berpengaruh positif dan signifikan terhadap Kinerja Karyawan dapat diterima karena bisa dibuktikan.

\begin{tabular}{|c|c|c|c|c|c|c|}
\hline \multirow{2}{*}{\multicolumn{2}{|c|}{ Model }} & \multicolumn{2}{|c|}{$\begin{array}{l}\text { Unstandardized } \\
\text { Coefficients }\end{array}$} & \multirow{2}{*}{$\begin{array}{l}\text { Standardized } \\
\text { Coefficients } \\
\text { Beta }\end{array}$} & \multirow[b]{2}{*}{$\mathrm{T}$} & \multirow[b]{2}{*}{ Sig. } \\
\hline & & B & Std. Error & & & \\
\hline \multirow[t]{2}{*}{1} & (Constant) & 9,368 & 2,572 & & 3,643 &, 001 \\
\hline & K3 & ,805 & ,056 & 900 & 14,426 &, 000 \\
\hline
\end{tabular}

\begin{tabular}{|c|c|c|c|c|c|c|}
\hline \multirow{2}{*}{\multicolumn{2}{|c|}{ Model }} & \multicolumn{2}{|c|}{$\begin{array}{l}\text { Unstandardized } \\
\text { Coefficients }\end{array}$} & \multirow{2}{*}{$\begin{array}{l}\text { Standardized } \\
\text { Coefficients } \\
\text { Beta }\end{array}$} & \multirow[b]{2}{*}{$\mathrm{T}$} & \multirow[b]{2}{*}{ Sig. } \\
\hline & & $\mathrm{B}$ & Std. Error & & & \\
\hline \multirow[t]{2}{*}{1} & (Constant) & 9,612 & 3,715 & & 2,587 & ,013 \\
\hline & $\begin{array}{l}\text { Komunikasi } \\
\text { Interpersonal }\end{array}$ & ,828 & ,083 & ,817 & 9,916 & ,000 \\
\hline
\end{tabular}

2. Uji F (uji secara simultan).

Uji $F$ digunakan untuk mengetahui apakah variabelvariabel bebas secara simultan berpengaruh terhadap variabel terikat. Olah data dengan aplikasi SPSS memunculkan nilai $F$ sebagaimana tertera dalam tabel anova berikut:

\begin{tabular}{|c|c|c|c|c|c|c|}
\hline \multicolumn{7}{|c|}{ ANOVA $^{a}$} \\
\hline \multicolumn{2}{|c|}{ Model } & Sum of Squares & $\mathrm{df}$ & Mean Square & $\mathrm{F}$ & Sig. \\
\hline \multirow[t]{3}{*}{1} & \begin{tabular}{|l|} 
Regression \\
\end{tabular} & 400,570 & 2 & 200,285 & 203,026 &, $000^{5}$ \\
\hline & Residual & 47,352 & 48 & ,986 & & \\
\hline & Total & 447,922 & 50 & & & \\
\hline
\end{tabular}


Nilai $F$ hitung dengan probability $(0,05)$ berdasarkan output SPSS adalah 203,026. Sedangkan nilai $F_{\text {tabel }}$ adalah 3,178. Sehingga $F$ hitung $(203,026)>F$ tabel $(3,178)$, signifikansi regresi adalah $0,00<$ 0,05 sehingga $\mathrm{H}_{\mathrm{o}}$ ditolak dan $\mathrm{H}_{\mathrm{a}}$ diterima. Berarti ada hubungan linier yang signifikan antara variabel bebas dengan variabel terikat secara simultan. Sehingga hipotesis "Keselamatan dan Kesehatan Kerja (K3) dan Komunikasi Interpersonal secara simultan berpengaruh positif dan signifikan terhadap Kinerja" dapat dibuktikan.

\section{E. Analisis Regresi Sederhana}

Dari output SPSS seperti tertera dalam tabel diperoleh persamaan regresi sederhana untuk masing-masing variabel. Persamaan regresi sederhana adalah: $\mathrm{Y}=\mathrm{a}+\mathrm{b}(\mathrm{x})$

1. Analisis Regresi Sederhana $X_{1}$ terhadap $\mathrm{Y}$.

$$
\begin{aligned}
& Y=a+b_{1} x_{1} \\
& Y=9,368+0,805 X_{1}
\end{aligned}
$$

Dari persamaan tersebut, berarti setiap kenaikan 1 skor variabel keselamatan dan kesehatan kerja (K3) akan berpengaruh positif pada kinerja sebesar 0,805 dengan asumsi variabel komunikasi interpersonal

\begin{tabular}{|c|c|c|c|c|c|c|}
\hline \multicolumn{7}{|c|}{ Coefficients $^{\mathrm{a}}$} \\
\hline \multirow{2}{*}{\multicolumn{2}{|c|}{ Model }} & \multicolumn{2}{|c|}{$\begin{array}{l}\text { Unstandardized } \\
\text { Coefficients }\end{array}$} & \multirow{2}{*}{$\begin{array}{l}\text { Standardized } \\
\text { Coefficients } \\
\text { Beta } \\
\end{array}$} & \multirow[b]{2}{*}{ T } & \multirow[b]{2}{*}{ Sig. } \\
\hline & & $B$ & Std. Error & & & \\
\hline \multirow[t]{2}{*}{1} & (Constant) & 9,368 & 2,572 & & 3,643 &, 001 \\
\hline & K3 &, 805 & ,056 & ,900 & 14,426 &, 000 \\
\hline
\end{tabular}
konstan.
2. Analisis Regresi Sederhana $X_{2}$ terhadap Y.

$\mathrm{Y}=9,612+0,828 \mathrm{X}_{2}$

Persamaan tersebut menginterpretasikan bahwa setiap kenaikan 1 skor variabel komunikasi interpersonal dapat meningkatkan skor kinerja sebesar 0,828 dengan asumsi variabel keselamatan dan kesehatan kerja

\begin{tabular}{|c|c|c|c|c|c|}
\hline \multicolumn{6}{|c|}{ Coefficients $^{a}$} \\
\hline \multirow{2}{*}{\multicolumn{2}{|c|}{ Model }} & \multicolumn{2}{|c|}{ Unstandardized Coefficients } & \multirow{2}{*}{$\frac{\text { Standardized Coefficients }}{\text { Beta }}$} & \multirow[b]{2}{*}{$\mathrm{T}$} \\
\hline & & $\mathrm{B}$ & Std. Error & & \\
\hline 1 & (Constant) & 9,612 & 3,715 & & 2,587 \\
\hline & $\begin{array}{l}\text { Komunikasi } \\
\text { Interpersonal }\end{array}$ & ,828 & ,083 & ,817 & 9,916 \\
\hline
\end{tabular}
konstan.

a. Dependent Variable: Kinerja

F. Analisis Regresi Berganda $X_{1}$ dan $\mathrm{X}_{2}$ terhadap $\mathrm{Y}$.
Persamaan yang diperoleh berdasarkan output SPSS adalah:

$\mathrm{Y}=\mathrm{a}+\mathrm{b}_{1} \mathrm{x}_{1}+\mathrm{b}_{2} \mathrm{x}_{2}$ 
$\mathrm{Y}=2,499+0,572_{1}+0,396 \mathrm{x}_{2}$

Dari persamaan regresi tersebut dapat dijabarkan sebagai berikut:

Nilai konstan (a) adalah 2,499 berarti jika keselamatan dan kesehatan kerja dan komunikasi interpersonal bernilai 0, maka Kinerja bernilai positif yaitu 2,499. Nilai koefisien regresi variabel keselamatan dan kesehatan kerja $\left(b_{1}\right)$ bernilai positif yaitu 0,572 berarti setiap peningkatan variabel keselamatan dan kesehatan kerja 1 maka kinerja akan meningkat 0,572. Sedangkan nilai koefisien variabel komunikasi interpersonal $\left(b_{2}\right)$ bernilai positif yaitu 0,396 berarti setiap peningkatan variabel komunikasi interpersonal 1 maka kinerja akan meningkat 0,396 dengan asumsi variabel lain tetap.

\begin{tabular}{|c|c|c|c|c|c|c|}
\hline \multicolumn{7}{|c|}{ Coefficients $^{a}$} \\
\hline \multirow{2}{*}{\multicolumn{2}{|c|}{ Model }} & \multicolumn{2}{|c|}{$\begin{array}{l}\text { Unstandardized } \\
\text { Coefficients }\end{array}$} & \multirow{2}{*}{$\begin{array}{l}\text { Standardized } \\
\text { Coefficients } \\
\text { Beta }\end{array}$} & \multirow[b]{2}{*}{$\mathrm{t}$} & \multirow{3}{*}{$\begin{array}{r}\text { Sig. } \\
, 268\end{array}$} \\
\hline & & $B$ & Std. Error & & & \\
\hline \multirow[t]{3}{*}{1} & (Constant) & 2,499 & 2,229 & & 1,121 & \\
\hline & K3 & ,572 & ,056 & ,639 & 10,149 & ,000 \\
\hline & $\begin{array}{l}\text { Komunikasi } \\
\text { Interpersonal }\end{array}$ & ,396 & ,064 & ,391 & 6,207 & ,000 \\
\hline
\end{tabular}

G. Analisis Korelasi Sederhana

Korelasi berkaitan dengan keeratan hubungan antar variabel. Untuk memberi gambaran mengenai kadar atau tingkat hubungan variable $\mathrm{X}_{1}, \mathrm{X}_{2}$ dan $\mathrm{Y}$, digunakan pedoman sebagai berikut: $0,00-0,199$ (sangat rendah); 0,20 - 0,399 (rendah); 0,40 - 0,599 (sedang); 0,60 -
0,799 (kuat); 0,80 - 0,100 (sangat kuat), Sugiono (2009: 252)

1. Analisis Korelasi Sederhana $X_{1}$ dan Y

Berdasarkan output SPSS 19 for windows diperoleh nilai koefisien korelasi sebesar 0,900. Artinya korelasi antara keselamatan dan kesehatan kerja (K3) dan kinerja sebesar 0,900 sangat kuat (mendekati 1)

\begin{tabular}{|l|r|r|r|r|}
\hline \multicolumn{3}{|l|}{ Model Summary } \\
\hline Model & R & R Square & Adjusted R Square & Std. Error of the Estimate \\
\hline 1 &, $900^{\mathrm{a}}$ &, 809 &, 806 & 1,31989 \\
\hline \multicolumn{7}{|l|}{} \\
$\begin{array}{l}\text { a. Predictors: (Constant), K3 } \\
\text { b. Dependent Variable: Kinerja }\end{array}$ \\
\hline
\end{tabular}


2. Analisis Korelasi Sederhana $X_{2}$ dan $\mathrm{Y}$

Berdasarkan output SPSS 19

for windows nilai koefisien korelasi sebesar 0,817. Artinya korelasi antara komunikasi interpersonal dan kinerja sebesar 0,817 sangat kuat (mendekati 1).

\begin{tabular}{|l|r|r|r|r|}
\hline \multicolumn{4}{|l|}{ Model Summary } \\
\hline Model & $\mathrm{R}$ & $\mathrm{R}$ Square & Adjusted R Square & Std. Error of the Estimate \\
\hline 1 &, $817^{\mathrm{a}}$ &, 667 &, 661 & 1,74362 \\
\hline
\end{tabular}

H. Koefisien Korelasi Berganda

Berdasarkan output SPSS 19 for windows diperoleh koefisien korelasi antara variabel $\mathrm{X}_{1}, \mathrm{X}_{2}$ terhadap variabel $\mathrm{Y}$ sebesar 0,946 berarti terjadi korelasi yang sangat kuat (mendekati 1).

\begin{tabular}{|c|c|c|c|}
\hline \multicolumn{4}{|c|}{ Model Summary } \\
\hline $\mathrm{R}$ & R Square & Adjusted R Square & Std. Error of the Estimate \\
\hline, $946^{\mathrm{a}}$ & ,894 & 890 & 6. \\
\hline
\end{tabular}

\section{Uji R (Koefisien Determinasi)}

1. Analisis Koefisien Determinasi $\mathrm{X}_{1}$ terhadap $\mathrm{Y}$.

Nilai koefisien determinasi yang diperoleh adalah sebesar
0,809 atau $80,9 \%$. Hal ini menunjukan prosentase pengaruh variabel keselamatan dan kesehatan kerja terhadap kinerja sebesar $80,9 \%$ sedangkan sisanya 19,1\% dipengaruhi variabel lain.

\begin{tabular}{|l|r|r|r|r|}
\hline \multicolumn{4}{|l|}{ Model Summary ${ }^{\text {b }}$} \\
\hline Model & R & R Square & Adjusted R Square & Std. Error of the Estimate \\
\hline 1 &, $900^{\mathrm{a}}$ &, 809 &, 806 & 1,31989 \\
\hline $\begin{array}{l}\text { a. Predictors: (Constant), K3 } \\
\text { b. Dependent Variable: Kinerja }\end{array}$
\end{tabular}


2. Analisis Koefisien Determinasi $\mathrm{X}_{2}$ terhadap $\mathrm{Y}$.

Nilai koefisien determinasi yang diperoleh adalah sebesar 0,667 atau $66,7 \%$. Berarti komunikasi interpersonal dapat mempengaruhi tingkat kinerja sebesar $66,7 \%$ sedangakan sisanya $32,3 \%$ dipengaruhi oleh variabel lain.

\begin{tabular}{|c|c|c|c|c|}
\hline \multicolumn{5}{|c|}{ Model Summary ${ }^{b}$} \\
\hline Model & $\mathrm{R}$ & R Square & Adjusted R Square & Std. Error of the Estimate \\
\hline 1 &, $817^{a}$ & ,667 & ,661 & 1,74362 \\
\hline
\end{tabular}

3. Analisis Koefisien Determinasi $\mathrm{X}_{1}, \mathrm{X}_{2}$ terhadap $\mathrm{Y}$.

Nilai koefisien determinasi yang diperoleh sebesar 0,894 atau $89,4 \%$. Hal ini menunjukan prosentase pengaruh variabel keselamatan dan kesehatan kerja dan komunikasi Interpersonal terhadap kinerja adalah sebesar $89,4 \%$ sedangkan sisanya $10,6 \%$ dipengaruhi variabel lain yang tidak diteliti.

\begin{tabular}{|c|c|c|c|c|}
\hline \multicolumn{5}{|c|}{ Model Summary ${ }^{b}$} \\
\hline Model & $\mathrm{R}$ & R Square & Adjusted R Square & Std. Error of the Estimate \\
\hline 1 &, $946^{a}$ & ,894 & 890 & ,99323 \\
\hline
\end{tabular}

\section{KESIMPULAN DAN SARAN}

\section{A. Kesimpulan}

1. Pengaruh keselamatan dan kesehatan kerja (k3) terhadap kinerja sangat kuat dengan koefisien korelasi $(r)=0,900$, sedangkan koefisien determinasi $(\mathrm{R})=80,9 \%$. Berdasarkan uji $t$ atau uji parsial, $t_{\text {hitung }}$ adalah 14,426 di mana hasil ini lebih besar dari $\mathrm{t}$ tabel. Berarti terdapat pengaruh yang signifikan antara keselamatan dan kesehatan kerja (K3) terhadap kinerja karyawan pada PT. Pardic Jaya Chemicals.

2. Pengaruh komunikasi interpersonal terhadap kinerja mempunyai pengaruh yang sangat kuat dengan koefisien korelasi $(r)=0,817$, sedangkan koefisien determinasi $(\mathrm{R})=$ $66,7 \%$. Berdasarkan uji parsial, $\mathrm{t}$ hitung adalah 9,916 di mana hasil ini lebih besar dari $\mathrm{t}$ tabel yang artinya terdapat pengaruh yang signifikan antara 
komunikasi interpersonal terhadap kinerja karyawan pada PT. Pardic Jaya Chemicals.

3. Pengaruh keselamatan dan kesehatan kerja (K3) dan komunikasi interpersonal secara simultan terhadap kinerja sangat kuat dengan koefisien korelasi sebesar 0,946. Koefisien determinasi $(\mathrm{R})=89,4 \%$ sisanya $10,6 \%$ dipengaruhi variabel lain yang tidak masuk dalam penelitian ini. Kemudian hasil uji simultan, $F$ hitung adalah 203,026 lebih besar dari $F_{\text {tabel }}$ yang nilainya 3,187 . Dapat disimpulkan bahwa terdapat pengaruh yang signifikan secara simultan anatara keselamatan dan kesehatan kerja (k3) dan komunikasi interpersonal terhadap kinerja karyawan pada PT. Pardic Jaya Chemicals. .

\section{B. SARAN}

1. Keselamatan dan kesehatan kerja (K3) sebagai salah satu program pemeliharaan karyawan harus diaplikasikan dengan baik agar tujuan perusahaan berjalan dengan baik. Perlu berbagai upaya untuk meningkatkan keselamatan dan kesehatan kerja dengan mengaplikasikan sertifikasi OHSAS yang telah diperoleh PT Pardic Jaya Chemicals dalam usaha meningkatkan kinerja karyawan.

2. Pihak manajemen harus dapat menciptakan dan memelihara kondisi komunikasi yang baik dan harmonis, karena komunikasi yang efektif merupakan kebutuhan sosial karyawan dalam hal berinteraksi dengan atasan, rekan kerja maupun bawahan yang harus dipenuhi. Pihak pimpinan harus dapat lebih memahami karyawannya, salah satunya melalui pendekatan komunikasi interpersonal yang baik sehingga mereka merasa diperhatikan, dan diakui.

3. Ternyata variabel bebas yang masuk dalam penelitian ini belum bisa menjawab persoalan kinerja secara keseluruhan, sehingga alangkah baiknya bila dilakukan penelitian lebih lanjut dengan variabel lainnya.

\section{DAFTAR PUSTAKA}

Dwiantara, Suharsono, dan Lukas, 2011, Komunikasi Bisnis Peran Komunikasi Interpersonal dalam Aktivitas Bisnis, Jakarta: PT. Buku Seru

Iman, Indra dan Siswandi, 2009, Aplikasi Manajemen Perusahaan, Analisis Kasus dan Pemecahannya, Jakarta: Mitra Wacana Media.

Mangkunegara, Anwar Prabu, 2010, Manajemen Sumber Daya Manusia Perusahaan, Bandung: PT. Remaja Rosdakarya 2014, Evaluasi Kinerja SDM, Bandung: PT. Refika Aditama

Nurjaman, Kadar, 2014, Manajemen Personalia, Bandung: Pustaka Setia 
Priansa, Donni J., dan Suwatno, 2011, Manajemen SDM dalam Organisasi Publik dan Bisnis, Bandung: CV. Alfabeta.

Sedarmayanti, 2013, Manajemen sumber Daya Manusia, Bandung:PT. Rafika Aditama

Sugiyono, 2009, Metode Penelitian Bisnis. Bandung: CV. Alfabeta.
2011, Metode Penelitian Kuantitatif, Kualitatif, dan R\&D, Bandung: Alfabeta

Sunyoto, Danang, 2011, Analisis Regresi dan Uji Hipotesis, Yokyakarta: CAPS.

Widodo, Suparno Eko, 2015, Manajemen Pengembangan Sumber Daya Manusia, Yokyakarta: Pustaka Pelajar 